Article

\title{
Cytotoxic and Anti-Inflammatory Metabolites from the Soft Coral Scleronephthya gracillimum
}

\author{
Hui-Yu Fang ${ }^{1}$, Chi-Hsin Hsu ${ }^{1}$, Chih-Hua Chao ${ }^{1,2,3}$, Zhi-Hong Wen ${ }^{1,4}$, Yang-Chang Wu ${ }^{2,3,5}$, \\ Chang-Feng Dai ${ }^{6}$ and Jyh-Horng Sheu ${ }^{1,4,7, *}$
}

1 Department of Marine Biotechnology and Resources, National Sun Yat-sen University, Kaohsiung 80424, Taiwan; E-Mails: ahui0220@yahoo.com.tw (H.-Y.F.); hsuch@mail.nsysu.edu.tw (C.-H.H.); chaochihhua@hotmail.com (C.-H.C.); wzh@mail.nsysu.edu.tw (Z.-H.W.)

2 School of Pharmacy, China Medical University, Taichung 40402, Taiwan; E-Mail: yachwu@mail.cmu.edu.tw

3 Chinese Medicine Research and Development Center, China Medical University Hospital, Taichung 40402, Taiwan

4 Asia-Pacific Ocean Research Center, National Sun Yat-sen University, Kaohsiung 80424, Taiwan

5 Center for Molecular Medicine, China Medical University Hospital, Taichung 40402, Taiwan

6 Institute of Oceanography, National Taiwan University, Taipei 10617, Taiwan; E-Mail: corallab@ntu.edu.tw

7 Graduate Institute of Natural Products, Kaohsiung Medical University, Kaohsiung 80708, Taiwan

* Author to whom correspondence should be addressed; E-Mail: sheu@mail.nsysu.edu.tw; Tel.: +886-7-525-2000 (ext. 5030); Fax: +886-7-525-5020.

Received: 20 March 2013; in revised form: 19 April 2013 / Accepted: 10 May 2013 /

Published: 29 May 2013

\begin{abstract}
Five new pregnane-type steroids, sclerosteroids J-N (1-5), and a diterpenoid with a new chemotype 3-methyl-5-(10'-acetoxy-2',6',10'-trimethylundecyl)-2-penten-5-olide (6), have been isolated from a soft coral Scleronephthya gracillimum. The structures of the metabolites were determined by extensive spectroscopic analysis. Compound $\mathbf{4}$ exhibited cytotoxicity against HepG2, A549, and MDA-MB-231 cancer cell lines. Furthermore, steroids $\mathbf{2}$ and $\mathbf{4}$ were found to significantly inhibit the accumulation of the pro-inflammatory iNOS protein, and 1, 2, 4 and 5 could effectively reduce the accumulation of COX-2 protein in LPS-stimulated RAW264.7 macrophage cells.
\end{abstract}

Keywords: soft coral; Scleronephthya gracillimum; cytotoxicity activity; anti-inflammatory activity 


\section{Introduction}

Soft corals have proven to be rich sources of terpenoids [1]. In previous studies, a series of novel secondary metabolites, including two alkyl glycerol ethers, one cembrane-based diterpenoid, one indole alkaoid and pregnane-type steroids have been isolated from the soft corals of the genus Scleronephthya [2-7]. During the course of search for bioactive metabolites from marine invertebrates, several pregnane-type compounds also have been isolated from soft corals, such as Carijoa sp. [8], Dendronephthya griffini [9], Dendronephthya sp. [10], Eunicella cavolini [11], Eunicella verrucosa [12], Muricea austera [13], Stereonephthya crystallina [14], and Subergorgia suberosa [15]. Our recent study of the chemical constituents of the Green Island soft coral Scleronephthya gracillimum [7] has yielded sclerosteroids A-I, of which some were found to exhibit significant cytotoxicity and anti-inflammatory activities. Our continuing chemical investigation on the same collection of this organism, with the aim of discovering other biologically active natural products, again led to the isolation of five new sclerosteroids $\mathrm{J}-\mathrm{N}$ (1-5), and a new type of diterpenoidal $\delta$-lactone, 3-methyl-5-(10'-acetoxy-2',6',10'-trimethylundecyl)-2-penten-5-olide (6). (Chart 1). The structures of 1-6 have been established by extensive spectroscopic analysis, including $2 \mathrm{D}$ NMR $\left({ }^{1} \mathrm{H}-{ }^{1} \mathrm{H}\right.$ COSY, HMQC, HMBC, and NOESY) correlations. The cytotoxicity of compounds $\mathbf{1}-\mathbf{6}$ against human liver carcinoma (HepG2), human lung carcinoma (A-549), and human breast carcinoma (MDA-MB-231) cell lines was measured. The ability of 1, 2, and 4-6 to inhibit the up-regulation of pro-inflammatory iNOS (inducible nitric oxide synthase) and COX-2 (cyclooxygenase-2) proteins in LPS (lipopolysaccharide)-stimulated RAW264.7 macrophage cells also was evaluated.

Chart 1. Structures of metabolites 1-6.

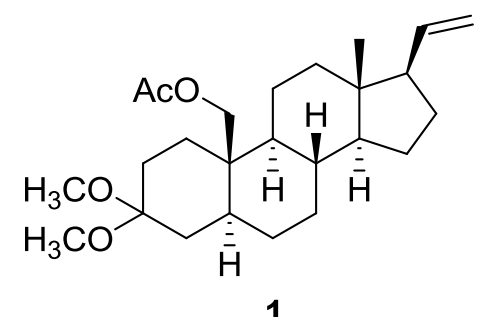

1

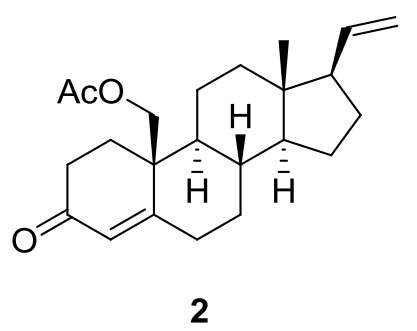

2

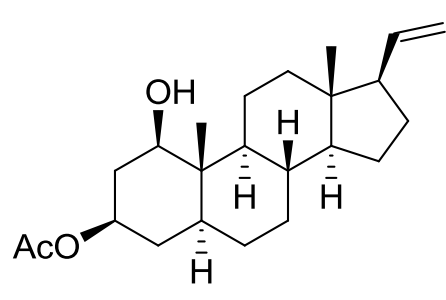

3
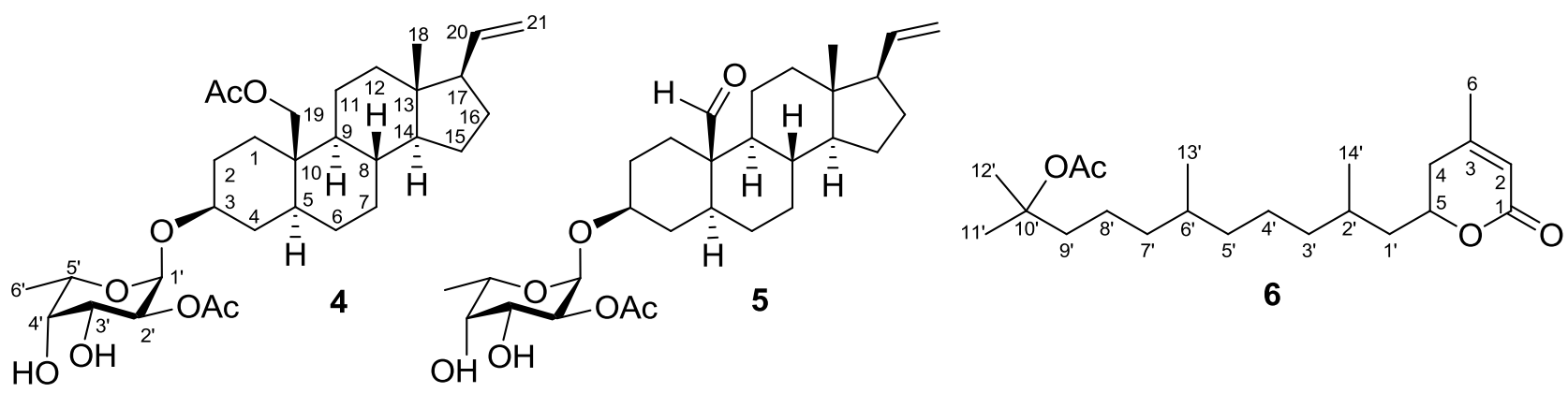


\section{Results and Discussion}

Sclerosteroid J (1) was obtained as colorless oil. The HRESIMS of $\mathbf{1}$ showed a pseudomolecular ion peak at $m / z 427.2827[\mathrm{M}+\mathrm{Na}]^{+}$, consistent with a molecular formula of $\mathrm{C}_{25} \mathrm{H}_{40} \mathrm{O}_{4}$ and requiring six degrees of unsaturation. The IR spectrum revealed the presence of ester-carbonyl group $\left(1739 \mathrm{~cm}^{-1}\right)$ in 1. The ${ }^{13} \mathrm{C}$ NMR and DEPT spectroscopic data (Table 1) showed the presence of 25 carbon signals, including 4 methyls, $10 \mathrm{sp}^{3}$ methylenes, $5 \mathrm{sp}^{3}$ methines, $1 \mathrm{sp}^{2}$ methine, $1 \mathrm{sp}^{2}$ methylene, $1 \mathrm{sp}^{2}$ quaternary and $3 \mathrm{sp}^{3}$ quaternary carbons. The ${ }^{1} \mathrm{H}$ NMR showed the presence of a tertiary methyl at $\delta_{\mathrm{H}}$ $0.57(3 \mathrm{H}, \mathrm{s})$, two methoxyls at $\delta_{\mathrm{H}} 3.15(3 \mathrm{H}, \mathrm{s})$, and $3.19(3 \mathrm{H}, \mathrm{s})$, an acetoxymethyl at $\delta_{\mathrm{H}} 4.16(1 \mathrm{H}, \mathrm{d}$, $J=12.0 \mathrm{~Hz}), 4.35(1 \mathrm{H}, \mathrm{d}, J=12.0 \mathrm{~Hz})$, and $2.05(3 \mathrm{H}, \mathrm{s})$, and a vinyl group at $\delta_{\mathrm{H}} 4.96(1 \mathrm{H}, \mathrm{br} \mathrm{d}, J=17.0 \mathrm{~Hz})$, $4.97(1 \mathrm{H}, \mathrm{br} \mathrm{d}, J=10.5 \mathrm{~Hz})$, and $5.74(1 \mathrm{H}, \mathrm{ddd}, J=17.0,10.5,7.5 \mathrm{~Hz})$. These spectroscopic data showed that 1 might be a pregnane with an acetoxymethyl substituent at $\mathrm{C}-10$ on the basis of the disappearance of an $\mathrm{H}_{3}-19$ singlet around $\delta_{\mathrm{H}} 0.80-1.10$ and the presence of an $\mathrm{AB}$ doublet at $\delta_{\mathrm{H}} 4.16(\mathrm{~J}=12.0 \mathrm{~Hz})$, and $4.35(J=12.0 \mathrm{~Hz})$. The molecular skeleton of 1 was determined by ${ }^{1} \mathrm{H}-{ }^{1} \mathrm{H}$ COSY and $\mathrm{HMBC}$ correlations as shown in Figure 1, in which C-3 $\left(\delta_{\mathrm{C}} 100.0\right)$ was HMBC correlated by protons of two methoxy groups and $\mathrm{CH}_{2}-2$. Thus, similar to known compound $11 \alpha$-acetoxy-3,3-dimethoxy-5 $\alpha$-pregn-20-ene [11], 1 also has two methoxyl substituents at C-3. The presence of an $\mathrm{sp}^{3}$ methylene substituent at C-19 was further confirmed by the HMBC correlations from $\mathrm{H}_{2}-19$ to C-1, C-5, C-9 and C-10. The relative stereochemistry of $\mathbf{1}$ was determined by correlations of a 2D NOE experiment (Figure 2). The observed NOE correlations between $\mathrm{H}-20$ and $\mathrm{H}_{3}-18, \mathrm{H}_{3}-18$ and $\mathrm{H}-8, \mathrm{H}-8$ and $\mathrm{H}_{2}-19, \mathrm{H}-17$ and $\mathrm{H}-14, \mathrm{H}-14$ and $\mathrm{H}-9$, and $\mathrm{H}-9$ and $\mathrm{H}-5$ revealed the $\beta$-orientation of $\mathrm{H}-8, \mathrm{H}_{3}-18, \mathrm{H}_{2}-19$ and $\mathrm{H}-20$, and $\alpha$-orientation of H-5, H-9, H-14 and H-17. On the basis of the above spectroscopic data, the structure of sclerosteroid J (1) was established as 19-acetoxy-3,3-dimethoxy-5 $\alpha$-pregn-20-ene.

Figure 1. ${ }^{1} \mathrm{H}-{ }^{1} \mathrm{H} \operatorname{COSY}(-)$ and $\operatorname{HMBC}(\rightarrow)$ correlations for $\mathbf{1}-\mathbf{6}$.
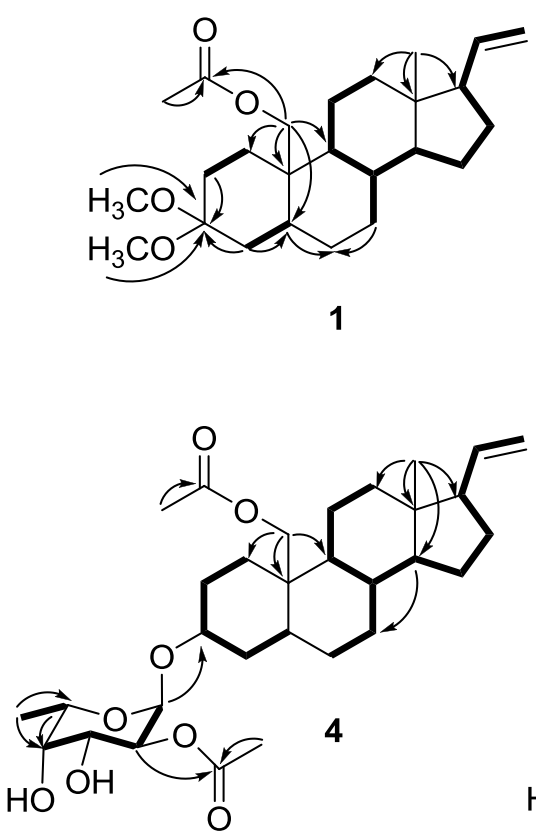
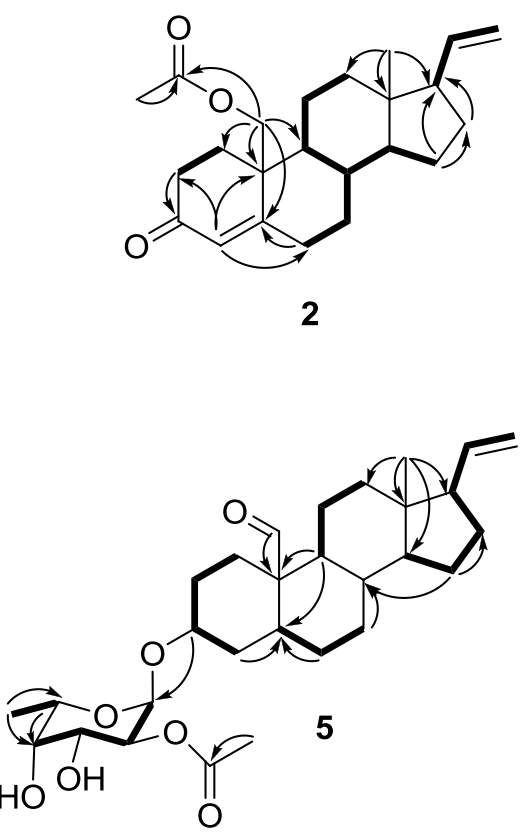
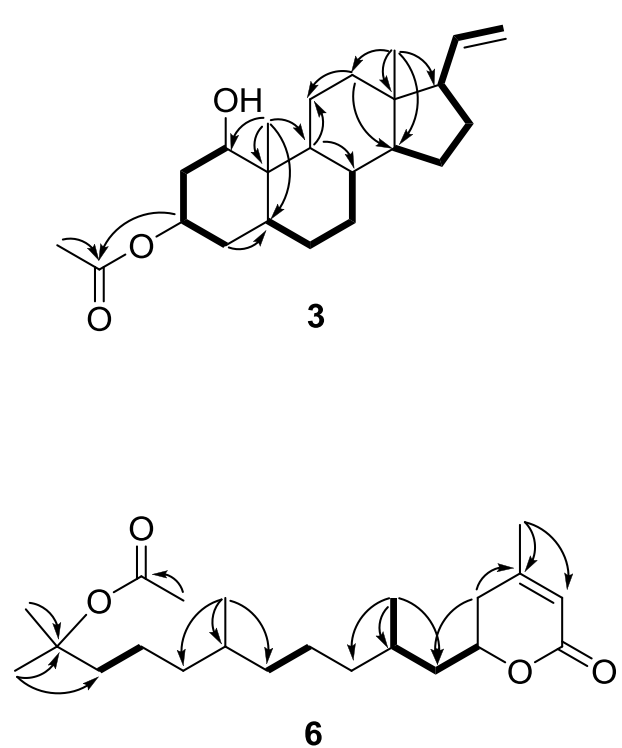
Table 1. ${ }^{1} \mathrm{H}$ and ${ }^{13} \mathrm{C}$ NMR spectroscopic data of $\mathbf{1}-\mathbf{3}$.

\begin{tabular}{|c|c|c|c|c|c|c|c|}
\hline \multirow{2}{*}{ Position } & \multicolumn{3}{|c|}{1} & \multicolumn{2}{|c|}{2} & \multicolumn{2}{|c|}{3} \\
\hline & & $\delta_{\mathrm{H}}(J \text { in } \mathrm{Hz})^{\mathrm{a}}$ & $\delta_{\mathrm{C}}$ (mult.) ${ }^{\mathrm{b}}$ & $\delta_{\mathrm{H}}(J \text { in } \mathrm{Hz})^{\mathrm{a}}$ & $\delta_{\mathrm{C}}$ (mult.) ${ }^{\mathrm{b}}$ & $\delta_{\mathrm{H}}(J \text { in } \mathrm{Hz})^{\mathrm{a}}$ & $\delta_{\mathrm{C}}$ (mult.) ${ }^{\mathrm{b}}$ \\
\hline \multirow[t]{2}{*}{1} & $\alpha$ & $1.01 \mathrm{~m}$ & $29.7, \mathrm{CH}_{2}{ }^{\mathrm{c}}$ & $1.84 \mathrm{~m}$ & $33.7, \mathrm{CH}_{2}$ & $\begin{array}{c}3.51 \mathrm{td} \\
(11.5,5.0)^{\mathrm{d}}\end{array}$ & $76.8, \mathrm{CH}$ \\
\hline & $\beta$ & $2.05 \mathrm{~m}$ & & $2.34 \mathrm{~m}$ & & & \\
\hline \multirow[t]{2}{*}{2} & $\alpha$ & $1.36 \mathrm{~m}$ & 28.4, $\mathrm{CH}_{2}$ & $2.35 \mathrm{~m}$ & 34.7, $\mathrm{CH}_{2}$ & $2.04 \mathrm{~m}$ & $38.1, \mathrm{CH}_{2}$ \\
\hline & $\beta$ & $1.92 \mathrm{~m}$ & & $2.61 \mathrm{~m}$ & & $1.53 \mathrm{~m}$ & \\
\hline 3 & & & 100.0, C & & 199.5, C & $\begin{array}{c}4.70 \mathrm{tt} \\
(11.5,5.0)\end{array}$ & $70.2, \mathrm{CH}$ \\
\hline \multirow[t]{2}{*}{4} & $\alpha$ & $1.42 \mathrm{~m}$ & $35.8, \mathrm{CH}_{2}$ & $5.91 \mathrm{~d}(1.5)$ & $126.7, \mathrm{CH}$ & $1.33 \mathrm{~m}$ & $34.0, \mathrm{CH}_{2}$ \\
\hline & $\beta$ & $1.70 \mathrm{~m}$ & & & & $1.56 \mathrm{~m}$ & \\
\hline 5 & & $1.46 \mathrm{~m}$ & $42.7, \mathrm{CH}$ & & 166.0, C & $1.08 \mathrm{~m}$ & $42.2, \mathrm{CH}$ \\
\hline \multirow[t]{2}{*}{6} & $\alpha$ & $1.26 \mathrm{~m}$ & $28.0, \mathrm{CH}_{2}$ & $2.34 \mathrm{~m}$ & $33.2, \mathrm{CH}_{2}$ & $1.37 \mathrm{~m}$ & 28.3, $\mathrm{CH}_{2}$ \\
\hline & $\beta$ & & & $2.41 \mathrm{~m}$ & & & \\
\hline \multirow[t]{2}{*}{7} & $\alpha$ & $0.97 \mathrm{~m}$ & $31.9, \mathrm{CH}_{2}$ & $1.08 \mathrm{~m}$ & $32.3, \mathrm{CH}_{2}$ & $1.67 \mathrm{~m}$ & $32.0, \mathrm{CH}_{2}$ \\
\hline & $\beta$ & $1.73 \mathrm{~m}$ & & $1.91 \mathrm{~m}$ & & $0.87 \mathrm{~m}$ & \\
\hline 8 & & $1.49 \mathrm{~m}$ & $35.9, \mathrm{CH}$ & $1.62 \mathrm{~m}$ & $36.3, \mathrm{CH}$ & $1.34 \mathrm{~m}$ & $36.0, \mathrm{CH}$ \\
\hline 9 & & $0.84 \mathrm{~m}$ & $54.3, \mathrm{CH}$ & $1.10 \mathrm{~m}$ & $54.4, \mathrm{CH}$ & $0.88 \mathrm{~m}$ & $54.9, \mathrm{CH}$ \\
\hline 10 & & & $38.3, \mathrm{C}$ & & $41.9, \mathrm{C}$ & & $41.6, \mathrm{C}$ \\
\hline \multirow[t]{2}{*}{11} & $\alpha$ & $1.63 \mathrm{~m}$ & $21.8, \mathrm{CH}_{2}$ & $1.67 \mathrm{~m}$ & 21.2, $\mathrm{CH}_{2}$ & $1.42 \mathrm{~m}$ & 24.1, $\mathrm{CH}_{2}$ \\
\hline & $\beta$ & $1.30 \mathrm{~m}$ & & $1.41 \mathrm{~m}$ & & $2.07 \mathrm{~m}$ & \\
\hline \multirow[t]{2}{*}{12} & $\alpha$ & $0.97 \mathrm{~m}$ & $37.9, \mathrm{CH}_{2}$ & $1.03 \mathrm{~m}$ & $37.5, \mathrm{CH}_{2}$ & $1.06 \mathrm{~m}$ & $37.8, \mathrm{CH}_{2}$ \\
\hline & $\beta$ & $1.65 \mathrm{~m}$ & & $1.73 \mathrm{~m}$ & & $1.68 \mathrm{~m}$ & \\
\hline 13 & & & 43.6, C & & $43.4, \mathrm{C}$ & & $43.0, \mathrm{C}$ \\
\hline 14 & & $1.00 \mathrm{~m}$ & $55.9, \mathrm{CH}$ & $1.00 \mathrm{~m}$ & $55.4, \mathrm{CH}$ & $0.99 \mathrm{~m}$ & $55.5, \mathrm{CH}$ \\
\hline \multirow[t]{2}{*}{15} & $\alpha$ & $1.67 \mathrm{~m}$ & 24.7, $\mathrm{CH}_{2}$ & $1.70 \mathrm{~m}$ & 24.6, $\mathrm{CH}_{2}$ & $1.66 \mathrm{~m}$ & 25.1, $\mathrm{CH}_{2}$ \\
\hline & $\beta$ & $1.17 \mathrm{~m}$ & & $1.23 \mathrm{~m}$ & & $1.14 \mathrm{~m}$ & \\
\hline \multirow[t]{2}{*}{16} & $\alpha$ & $1.77 \mathrm{~m}$ & 27.2, $\mathrm{CH}_{2}$ & $1.81 \mathrm{~m}$ & 27.1, $\mathrm{CH}_{2}$ & $1.74 \mathrm{~m}$ & 27.0, $\mathrm{CH}_{2}$ \\
\hline & $\beta$ & $1.54 \mathrm{~m}$ & & $1.58 \mathrm{~m}$ & & $1.53 \mathrm{~m}$ & \\
\hline 17 & & $1.93 \mathrm{~m}$ & $55.3, \mathrm{CH}$ & $1.96 \mathrm{~m}$ & $55.1, \mathrm{CH}$ & $1.93 \mathrm{~m}$ & $55.5, \mathrm{CH}$ \\
\hline 18 & & $0.57 \mathrm{~s}$ & $13.0, \mathrm{CH}_{3}$ & $0.64 \mathrm{~s}$ & $12.9, \mathrm{CH}_{3}$ & $0.58 \mathrm{~s}$ & $12.8, \mathrm{CH}_{3}$ \\
\hline \multirow[t]{2}{*}{19} & & $4.16 \mathrm{~d}(12.0)^{\mathrm{d}}$ & $62.5, \mathrm{CH}_{2}$ & $4.17 \mathrm{~d}(11.0)$ & 67.0, $\mathrm{CH}_{2}$ & $0.87 \mathrm{~s}$ & 6.7, $\mathrm{CH}_{3}$ \\
\hline & & $4.35 \mathrm{~d}(12.0)$ & & $4.67 \mathrm{~d}(11.0)$ & & & \\
\hline 20 & & $\begin{array}{c}5.74 \mathrm{ddd} \\
(17.0,10.5,7.5)\end{array}$ & $140.0, \mathrm{CH}$ & $\begin{array}{c}5.74 \mathrm{ddd} \\
(17.0,11.0,6.5)\end{array}$ & $139.2, \mathrm{CH}$ & $\begin{array}{c}5.75 \mathrm{ddd} \\
(17.0,11.0,7.5)\end{array}$ & $139.8, \mathrm{CH}$ \\
\hline \multirow[t]{2}{*}{21} & & 4.96 br d (17.0) & $114.5, \mathrm{CH}_{2}$ & 4.98 br d (17.0) & $114.9, \mathrm{CH}_{2}$ & 4.95 br d (17.0) & $114.4, \mathrm{CH}_{2}$ \\
\hline & & $4.97 \mathrm{brd}(10.5)$ & & 4.99 br d (11.0) & & 4.96 br d (11.0) & \\
\hline $\mathrm{OH}$ & & & & & & $1.25 \mathrm{~d}(11.5)$ & \\
\hline \multirow[t]{2}{*}{ OAc } & & $2.05 \mathrm{~s}$ & $21.2, \mathrm{CH}_{3}$ & $2.00 \mathrm{~s}$ & $21.0, \mathrm{CH}_{3}$ & $2.02 \mathrm{~s}$ & $21.3, \mathrm{CH}_{3}$ \\
\hline & & & 171.2, C & & $170.7, \mathrm{C}$ & & $170.6, \mathrm{C}$ \\
\hline \multirow[t]{2}{*}{$\mathrm{OMe}$} & & $3.15 \mathrm{~s}$ & $47.5, \mathrm{CH}_{3}$ & & & & \\
\hline & & $3.19 \mathrm{~s}$ & 47.6, $\mathrm{CH}_{3}$ & & & & \\
\hline
\end{tabular}

${ }^{\text {a }}$ Spectra recorded at $500 \mathrm{MHz}$ in $\mathrm{CDCl}_{3} ;{ }^{\mathrm{b}}$ Spectra recorded at $125 \mathrm{MHz}$ in $\mathrm{CDCl}_{3} ;{ }^{\mathrm{c}}$ Deduced from DEPT; ${ }^{\mathrm{d}} J$ values $(\mathrm{Hz})$ in parentheses. 
Figure 2. Key NOESY Correlations for 1-5.
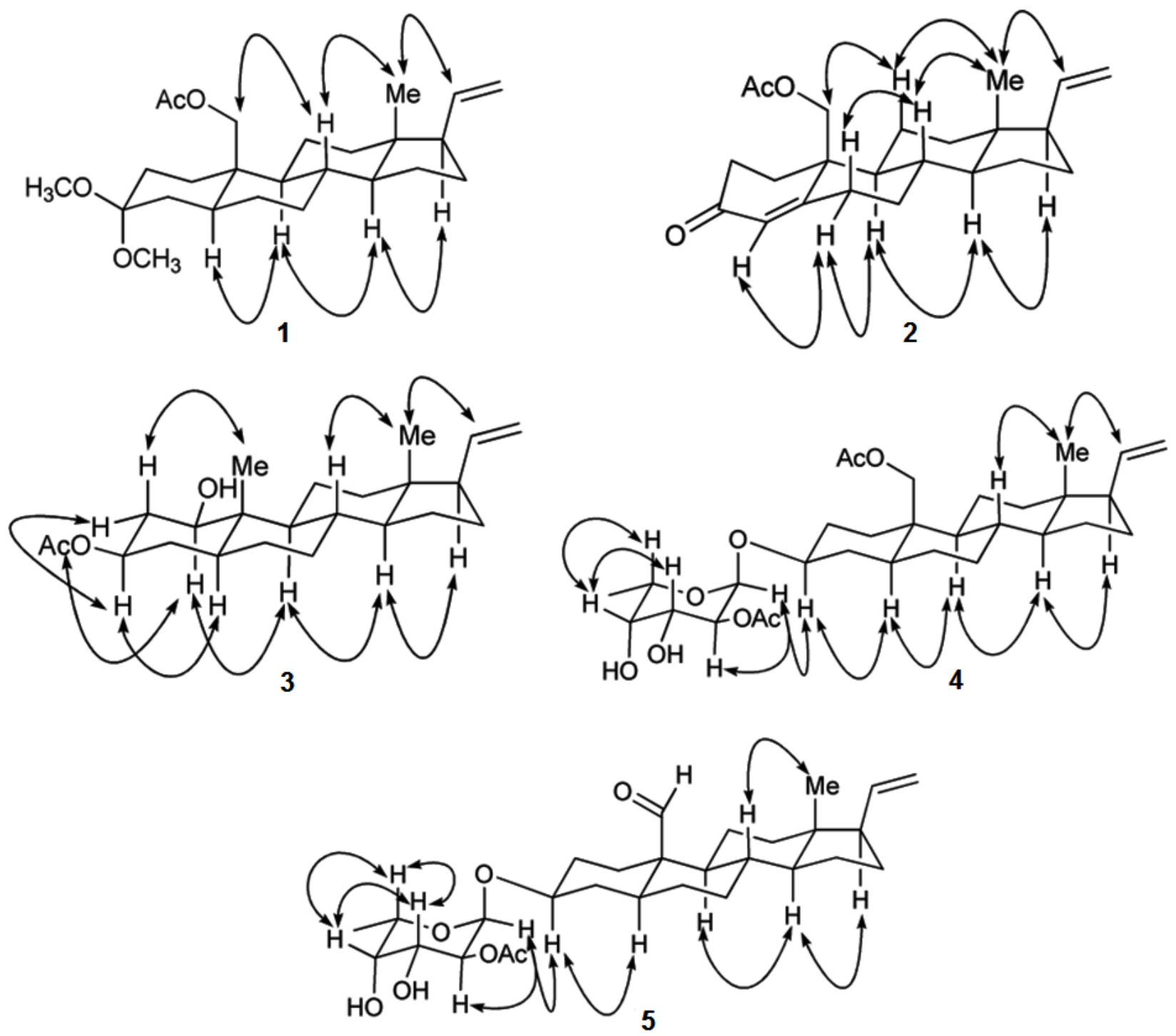

Sclerosteroid K (2) has a molecular formula of $\mathrm{C}_{23} \mathrm{H}_{32} \mathrm{O}_{3}$ as determined by HRESIMS, appropriate for eight degrees of unsaturation. The ${ }^{1} \mathrm{H}$ and ${ }^{13} \mathrm{C}$ NMR, including DEPT spectrum, exhibited the presence of a tertiary methyl $\left(\delta_{\mathrm{H}} 0.64,3 \mathrm{H}, \mathrm{s} ; \delta_{\mathrm{C}} 12.9\right)$, a primary acetoxymethyl group $\left(\delta_{\mathrm{H}} 4.17,1 \mathrm{H}, \mathrm{d}\right.$, $\left.J=11.0 \mathrm{~Hz} ; 4.67,1 \mathrm{H}, \mathrm{d}, J=11.0 \mathrm{~Hz} ; \delta_{\mathrm{C}} 67.0\right)$, a vinyl group $\left(\delta_{\mathrm{H}} 4.98,1 \mathrm{H}, \mathrm{br} \mathrm{d}, J=17.0 \mathrm{~Hz} ; 4.99,1 \mathrm{H}, \mathrm{br}\right.$ $\mathrm{d}, J=11.0 \mathrm{~Hz} ; 5.74,1 \mathrm{H}$, ddd $\left.J=17.0,11.0,6.5 \mathrm{~Hz} ; \delta_{\mathrm{C}} 114.9,139.2\right)$, and an enone group $\left(\delta_{\mathrm{H}} 5.91,1 \mathrm{H}\right.$, $\mathrm{d}, J=1.5 \mathrm{~Hz} ; \delta_{\mathrm{C}} 126.7,166.0,199.5$ ) (Table 1). These spectroscopic data showed that 2 might have a 4,20-dien-3-one-pregnane skeleton [16,17] with an acetoxymethyl substituent at C-10 on the basis of the disappearance of an $\mathrm{H}_{3}-19$ singlet around $\delta_{\mathrm{H}} 0.80-1.10$ and the presence of an $\mathrm{AB}$ doublet at $\delta_{\mathrm{H}} 4.17$ $(J=11.0 \mathrm{~Hz})$ and $4.67(J=11.0 \mathrm{~Hz})$ and a doublet vinyl proton at $\delta_{\mathrm{H}} 5.91(J=1.5 \mathrm{~Hz})$. From COSY spectrum measured in $\mathrm{CDCl}_{3}$, it was possible to establish thirteen proton sequences from $\mathrm{H}_{2}-1$ to $\mathrm{H}_{2}-2$, $\mathrm{H}_{2}-6$ to $\mathrm{H}_{2}-7, \mathrm{H}_{2}-7$ to $\mathrm{H}-8, \mathrm{H}-8$ to $\mathrm{H}-9$ and $\mathrm{H}-14$, $\mathrm{H}-9$ to $\mathrm{H}_{2}-11, \mathrm{H}_{2}-11$ to $\mathrm{H}_{2}-12, \mathrm{H}-14$ to $\mathrm{H}_{2}-15, \mathrm{H}-17$ to $\mathrm{H}-20$, and $\mathrm{H}-20$ to $\mathrm{H}_{2}-21$ (Figure 1). The HMBC correlations of $\mathrm{H}_{2}-19$ to C-1, C-5, C-9 and C-10; $\mathrm{H}_{3}-18$ to $\mathrm{C}-12, \mathrm{C}-13$ and $\mathrm{C}-17 ; \mathrm{H}_{2}-2$ to $\mathrm{C}-3 ; \mathrm{H}-4$ to $\mathrm{C}-2, \mathrm{C}-6$ and $\mathrm{C}-10 ; \mathrm{H}_{2}-15$ to $\mathrm{C}-16$ and $\mathrm{C}-17$, permitted the connection of the carbon skeleton. The observed NOESY correlations between $\mathrm{H}_{3}-18$ and both H-20 and H-8, H-8 and H-6 $\beta, H-11 \beta$ and $\mathrm{H}_{2}-19, \mathrm{H}-14$ and both $\mathrm{H}-17$ and H-9, H-6 $\alpha$ and both H-4 
and $\mathrm{H}-9$ revealed the $\beta$-orientation of $\mathrm{H}-6 \beta, \mathrm{H}-8, \mathrm{H}-11 \beta, \mathrm{H}_{3}-18, \mathrm{H}_{2}-19$, and $\mathrm{H}-20$ and $\alpha$-orientation of H-4, H-6 $\alpha, H-9, H-14$, and H-17 (Figure 2). On the basis of the above spectroscopic data, the structure of 2 was established as 19-acetoxypregna-4,20-dien-3-one.

Sclerosteroid L (3) was shown by HRESIMS to possess the molecular formula $\mathrm{C}_{23} \mathrm{H}_{36} \mathrm{O}_{3}(\mathrm{~m} / \mathrm{z}$ $\left.383.2559[\mathrm{M}+\mathrm{Na}]^{+}\right)$. The IR absorptions at 3568 and $1712 \mathrm{~cm}^{-1}$ suggested the presence of hydroxy and carbonyl groups. The ${ }^{13} \mathrm{C}$ NMR and DEPT spectrum of $\mathbf{3}$ were similar to those of $5 \alpha$-pregn-20-en-1 $\alpha, 3 \alpha$-diol 3 -acetate [18], with small differences observed in the A-ring. This was confirmed by the COSY correlations between $\mathrm{H}-1 / \mathrm{H}_{2}-2, \mathrm{H}_{2}-2 / \mathrm{H}-3$, and $\mathrm{H}-3 / \mathrm{H}_{2}-4$, revealing that 3 is an epimer of $5 \alpha$-pregn-20-en-1 $\alpha, 3 \alpha$-diol 3 -acetate (Figure 1). The planar structure of 3 was further confirmed by analysis of ${ }^{1} \mathrm{H}-{ }^{1} \mathrm{H}$ COSY and $\mathrm{HMBC}$ correlations (Figure 1). The ${ }^{1} \mathrm{H}-{ }^{1} \mathrm{H}$ COSY correlations allowed the establishment of two additional spin systems from $\mathrm{H}-5$ to $\mathrm{H}-8$ and $\mathrm{H}-14$ to $\mathrm{H}-17$ through $\mathrm{H}-20$ to $\mathrm{H}_{2}-21$. Key HMBC correlations of $\mathrm{H}_{3}-19$ to $\mathrm{C}-1, \mathrm{C}-5, \mathrm{C}-9$ and $\mathrm{C}-10 ; \mathrm{H}_{3}-18$ to C-12, C-13, C-14 and C-17; H-4 to and C-5; H-9 to C-8 and C-11; $\mathrm{H}_{2}-12$ to C-11 and C-14, permitted establishment of the planar structure of $\mathbf{3}$. The observed NOESY correlations between $\mathrm{H}-20$ and $\mathrm{H}_{3}-18$, $\mathrm{H}_{3}-19$ and $\mathrm{H}-2 \beta, \mathrm{H}_{3}-18$ and $\mathrm{H}-8, \mathrm{H}-17$ and $\mathrm{H}-14, \mathrm{H}-14$ and $\mathrm{H}-9, \mathrm{H}-9$ and $\mathrm{H}-1 \alpha, \mathrm{H}-5$ and $\mathrm{H}-3 \alpha, \mathrm{H}-3 \alpha$ and $\mathrm{H}-2 \alpha$, and $\mathrm{H}-2 \alpha$ and $\mathrm{H}-1 \alpha$ revealed the $\beta$-orientation of $\mathrm{H}-2 \beta, \mathrm{H}-8, \mathrm{H}_{3}-18, \mathrm{H}_{3}-19$, and $\mathrm{H}-20$ and $\alpha$-orientation of H-1 $\alpha, \mathrm{H}-2 \alpha, \mathrm{H}-3 \alpha, \mathrm{H}-5, \mathrm{H}-9, \mathrm{H}-14$, and H-17 (Figure 2). Analysis of the coupling constants of $\mathrm{H}-1\left(\delta_{\mathrm{H}} 3.51,1 \mathrm{H}, \mathrm{td}, J=11.5,5.0 \mathrm{~Hz}\right)$ and $\mathrm{H}-3\left(\delta_{\mathrm{H}} 4.70,1 \mathrm{H}, \mathrm{tt}, J=11.5,5.0 \mathrm{~Hz}\right)$ confirming the $\beta$-orientations of $1-\mathrm{OH}$ and $3-\mathrm{OH}$. Therefore, the structure of $\mathbf{3}$ could be established unambiguously as $5 \alpha$-pregn-20-en-1 $\beta, 3 \beta$-diol 3 -acetate.

The molecular formula of sclerosteroid $\mathrm{M}(4)$ was found to be $\mathrm{C}_{31} \mathrm{H}_{48} \mathrm{O}_{8}$, as established HRESIMS, ${ }^{13} \mathrm{C}$ NMR, and DEPT data, indicating eight degrees of unsaturation. The ${ }^{1} \mathrm{H}$ and ${ }^{13} \mathrm{C}$ NMR spectra of 4 displayed the signals of a vinyl group $\left(\delta_{\mathrm{H}} 4.95,1 \mathrm{H}, \mathrm{br} \mathrm{d}, J=18.0 \mathrm{~Hz} ; 4.96,1 \mathrm{H}\right.$, br d, $J=10.0 \mathrm{~Hz} ; 5.74$, $\left.1 \mathrm{H}, \mathrm{ddd}, J=18.0,10.0,8.0 \mathrm{~Hz} ; \delta_{\mathrm{C}} 114.5,139.8\right)$, two ester carbonyl $\left(\delta_{\mathrm{C}} 171.3,171.5\right)$, and two acetate methyl groups $\left(\delta_{\mathrm{H}} 2.06,3 \mathrm{H}, \mathrm{s} ; 2.13,3 \mathrm{H}, \mathrm{s} ; \delta_{\mathrm{C}} 21.1,21.2\right)$. Therefore, 4 possesses five rings. The ${ }^{1} \mathrm{H}$ and ${ }^{13} \mathrm{C}$ NMR spectroscopic data of $\mathbf{4}$ were similar to those of sclerosteroid A [7], except for the appearing of six additional carbon signals at $\delta_{\mathrm{C}} 94.6(\mathrm{CH}), 72.0(\mathrm{CH}), 68.6(\mathrm{CH}), 72.3(\mathrm{CH}), 65.3(\mathrm{CH})$, and 16.1 $\left(\mathrm{CH}_{3}\right)$, an anomeric proton signal at $\delta_{\mathrm{H}} 5.13(1 \mathrm{H}, \mathrm{d}, J=4.0 \mathrm{~Hz})$, as well as a methyl doublet at $\delta_{\mathrm{H}} 1.28$, suggesting the presence of a $6^{\prime}$-deoxyhexose unit. This hexose appeared to be the $\mathrm{C}-2^{\prime}$ monoacetate derivative of fucopyranose by comparison of ${ }^{1} \mathrm{H}$ and ${ }^{13} \mathrm{C}$ NMR data with those reported previously [7] and on the basis of the results of ${ }^{1} \mathrm{H}-{ }^{1} \mathrm{H}$ COSY, HMBC, and NOESY experiments, in particular the HMBC correlation from $\mathrm{H}-2^{\prime}\left(\delta_{\mathrm{H}} 4.86\right)$ to the acetate carbonyl carbon $\left(\delta_{\mathrm{C}} 171.5\right)$ (Figure 1). The sugar moiety was found to be connected with $\mathrm{C}-3$ of the aglycon by HMBC correlation of $\mathrm{H}-1^{\prime}$ and $\mathrm{C}-3$. The anomeric proton $\mathrm{H}-1^{\prime}\left(\delta_{\mathrm{H}} 5.13\right)$ has a small coupling constant, indicating the equatorial orientation of this proton. The relative configuration of the aglycon of 4 was further determined by NOESY experiment (Figure 2). On the basis of the above analysis, the structure of $\mathbf{4}$ was established as $3 \beta$-(2'-O-acetyl- $\alpha$-L-fucopyranosyloxy)-5 $\alpha$-pregn-20-en-19-ol 19-acetate.

Sclerosteroid N (5) had a molecular formula of $\mathrm{C}_{29} \mathrm{H}_{44} \mathrm{O}_{7}$ as established by HRESIMS. The ${ }^{1} \mathrm{H}$ and ${ }^{13} \mathrm{C}$ NMR spectroscopic data of $\mathbf{5}$ were similar to those of $\mathbf{4}$, except for the replacement of the C-10 acetoxymethyl group in $\mathbf{4}$ by an aldehyde $\left(\delta_{\mathrm{H}} 10.0,1 \mathrm{H}, \mathrm{s} ; \delta_{\mathrm{C}} 208.5\right)$ in $\mathbf{5}$ (Table 2). The relative configuration and connection of the aglycon and sugar residue of 5 were further determined by ${ }^{1} \mathrm{H}-{ }^{1} \mathrm{H}$ 
COSY, HMBC, and NOESY experiments (Figures 1 and 2). Thus, the structure of 5 was assigned as $3 \beta$-(2'-O-acetyl- $\alpha$-L-fucopyranosyloxy)-5 $\alpha$-pregna-20-en-19-al.

Table 2. ${ }^{1} \mathrm{H}$ and ${ }^{13} \mathrm{C}$ NMR spectroscopic data of 4-6.

\begin{tabular}{|c|c|c|c|c|c|c|c|}
\hline \multirow{2}{*}{ Position } & \multicolumn{3}{|c|}{4} & \multicolumn{2}{|c|}{5} & \multicolumn{2}{|c|}{6} \\
\hline & & $\delta_{\mathrm{H}}(J \text { in } \mathrm{Hz})^{\mathrm{a}}$ & $\delta_{\mathrm{C}}$ (mult.) ${ }^{b}$ & $\delta_{\mathrm{H}}(J \text { in } \mathrm{Hz})^{\mathrm{c}}$ & $\delta_{C}$ (mult.) ${ }^{d}$ & $\delta_{\mathrm{H}}(J \text { in } \mathrm{Hz})^{\mathrm{c}}$ & $\delta_{\mathrm{C}}$ (mult.) ${ }^{\mathrm{d}}$ \\
\hline \multirow[t]{2}{*}{1} & $\alpha$ & $0.91 \mathrm{~m}$ & $31.9, \mathrm{CH}_{2}{ }^{\mathrm{e}}$ & $0.93 \mathrm{~m}$ & $31.0, \mathrm{CH}_{2}$ & & $165.4, \mathrm{C}$ \\
\hline & $\beta$ & $2.23 \mathrm{~m}$ & & $\begin{array}{c}2.40 \mathrm{dt} \\
(14.0,4.0)\end{array}$ & & & \\
\hline \multirow[t]{2}{*}{2} & $\alpha$ & $1.83 \mathrm{~m}$ & 29.3, $\mathrm{CH}_{2}$ & $1.40 \mathrm{~m}$ & $30.3, \mathrm{CH}_{2}$ & $5.81 \mathrm{~s}$ & 116.6, CH \\
\hline & $\beta$ & $1.44 \mathrm{~m}$ & & $1.87 \mathrm{~m}$ & & & \\
\hline 3 & & $3.53 \mathrm{~m}$ & 76.7, CH & $3.50 \mathrm{~m}$ & 76.7, CH & & 157.0, C \\
\hline \multirow[t]{2}{*}{4} & $\alpha$ & $1.62 \mathrm{~m}$ & $34.4, \mathrm{CH}_{2}$ & $1.71 \mathrm{~m}$ & $35.9, \mathrm{CH}_{2}$ & $2.22 \mathrm{~d}(4.4)^{\mathrm{f}}$ & $35.0, \mathrm{CH}_{2}$ \\
\hline & $\beta$ & $1.33 \mathrm{~m}$ & & $1.23 \mathrm{~m}$ & & $2.27 \mathrm{~m}$ & \\
\hline 5 & & $1.25 \mathrm{~m}$ & $44.8, \mathrm{CH}$ & $1.36 \mathrm{~m}$ & $43.3, \mathrm{CH}$ & $4.46 \mathrm{~m}$ & 75.7, $\mathrm{CH}$ \\
\hline \multirow[t]{2}{*}{6} & $\alpha$ & $1.27 \mathrm{~m}$ & $28.3, \mathrm{CH}_{2}$ & $1.53 \mathrm{~m}$ & 28.3, $\mathrm{CH}_{2}$ & $1.99 \mathrm{~s}$ & $23.0, \mathrm{CH}_{3}$ \\
\hline & $\beta$ & & & $1.91 \mathrm{~m}$ & & & \\
\hline \multirow[t]{2}{*}{7} & $\alpha$ & $0.92 \mathrm{~m}$ & 32.0, $\mathrm{CH}_{2}$ & $1.07 \mathrm{~m}$ & 32.0, $\mathrm{CH}_{2}$ & & \\
\hline & $\beta$ & $1.75 \mathrm{~m}$ & & $1.90 \mathrm{~m}$ & & & \\
\hline 8 & & $1.50 \mathrm{~m}$ & $35.9, \mathrm{CH}$ & $1.43 \mathrm{~m}$ & $37.0, \mathrm{CH}$ & & \\
\hline 9 & & $0.75 \mathrm{~m}$ & $54.5, \mathrm{CH}$ & $0.95 \mathrm{~m}$ & $52.8, \mathrm{CH}$ & & \\
\hline 10 & & & $38.1, \mathrm{C}$ & & $51.8, \mathrm{C}$ & & \\
\hline \multirow[t]{2}{*}{11} & $\alpha$ & $1.65 \mathrm{~m}$ & 21.8, $\mathrm{CH}_{2}$ & $1.26 \mathrm{~m}$ & 21.4, $\mathrm{CH}_{2}$ & & \\
\hline & $\beta$ & $1.35 \mathrm{~m}$ & & $1.69 \mathrm{~m}$ & & & \\
\hline \multirow[t]{2}{*}{12} & $\alpha$ & $0.97 \mathrm{~m}$ & $37.8, \mathrm{CH}_{2}$ & $0.98 \mathrm{~m}$ & 37.3, $\mathrm{CH}_{2}$ & & \\
\hline & $\beta$ & $1.68 \mathrm{~m}$ & & $1.66 \mathrm{~m}$ & & & \\
\hline 13 & & & 43.6, C & & $43.4, \mathrm{C}$ & & \\
\hline 14 & & $1.02 \mathrm{~m}$ & $55.9, \mathrm{CH}$ & $0.93 \mathrm{~m}$ & $55.7, \mathrm{CH}$ & & \\
\hline \multirow[t]{2}{*}{15} & $\alpha$ & $1.68 \mathrm{~m}$ & 24.7, $\mathrm{CH}_{2}$ & $1.14 \mathrm{~m}$ & 24.6, $\mathrm{CH}_{2}$ & & \\
\hline & $\beta$ & $1.18 \mathrm{~m}$ & & $1.66 \mathrm{~m}$ & & & \\
\hline \multirow[t]{2}{*}{16} & $\alpha$ & $1.79 \mathrm{~m}$ & 27.2, $\mathrm{CH}_{2}$ & $1.50 \mathrm{~m}$ & 27.1, $\mathrm{CH}_{2}$ & & \\
\hline & $\beta$ & $1.56 \mathrm{~m}$ & & $1.76 \mathrm{~m}$ & & & \\
\hline 17 & & $\begin{array}{c}1.95 \mathrm{dt} \\
(18.0,8.0)^{\mathrm{f}}\end{array}$ & $55.3, \mathrm{CH}$ & $1.93 \mathrm{~m}$ & $55.3, \mathrm{CH}$ & & \\
\hline 18 & & $0.57 \mathrm{~s}$ & 13.0, $\mathrm{CH}_{3}$ & $0.52 \mathrm{~s}$ & $12.8, \mathrm{CH}_{3}$ & & \\
\hline \multirow[t]{3}{*}{19} & & $4.20 \mathrm{~d}(12.0)$ & $62.8, \mathrm{CH}_{2}$ & $10.0 \mathrm{~s}$ & $208.5, \mathrm{CH}$ & & \\
\hline & & $4.34 \mathrm{~d}(12.0)$ & & & & & \\
\hline & & $5.74 \mathrm{ddd}$ & & $5.72 \mathrm{ddd}$ & & & \\
\hline 20 & & $\begin{array}{c}(18.0,10.0 \\
8.0)\end{array}$ & $139.8, \mathrm{CH}$ & $\begin{array}{c}(18.0,10.0 \\
8.0)\end{array}$ & $139.5, \mathrm{CH}$ & & \\
\hline \multirow[t]{2}{*}{21} & & $\begin{array}{c}4.95 \mathrm{br} \mathrm{d} \\
(18.0)\end{array}$ & $114.5, \mathrm{CH}_{2}$ & $\begin{array}{c}4.96 \mathrm{br} \mathrm{d} \\
(18.0)\end{array}$ & 114.7, $\mathrm{CH}_{2}$ & & \\
\hline & & $\begin{array}{c}4.96 \mathrm{br} \mathrm{d} \\
(10.0)\end{array}$ & & $\begin{array}{c}4.97 \mathrm{br} \mathrm{d} \\
(10.0)\end{array}$ & & & \\
\hline
\end{tabular}


Table 2. Cont.

\begin{tabular}{|c|c|c|c|c|c|c|}
\hline $1^{\prime}$ & $5.13 \mathrm{~d}(4.0)$ & $94.6, \mathrm{CH}$ & $5.12 \mathrm{~d}(3.6)$ & $94.8, \mathrm{CH}$ & $\begin{array}{l}1.52 \mathrm{~m} \\
1.68 \mathrm{~m}\end{array}$ & $42.3, \mathrm{CH}_{2}$ \\
\hline $2^{\prime}$ & $\begin{array}{c}4.86 \mathrm{dd} \\
(10.5,4.0)\end{array}$ & $72.0, \mathrm{CH}$ & $\begin{array}{c}4.84 \mathrm{dd} \\
(10.0,3.6)\end{array}$ & $72.0, \mathrm{CH}$ & $2.66 \mathrm{~m}$ & $28.9, \mathrm{CH}$ \\
\hline $3^{\prime}$ & $\begin{array}{c}4.00 \mathrm{dd} \\
(10.5,3.5)\end{array}$ & $68.6, \mathrm{CH}$ & $\begin{array}{c}3.98 \mathrm{dd} \\
(10.0,3.2)\end{array}$ & $68.5, \mathrm{CH}$ & $1.34 \mathrm{~m}$ & $36.9, \mathrm{CH}_{2}$ \\
\hline $4^{\prime}$ & $3.81 \mathrm{~d}(3.5)$ & $72.3, \mathrm{CH}$ & $3.80 \mathrm{~d}(3.2)$ & $72.3, \mathrm{CH}$ & $\begin{array}{l}1.20 \mathrm{~m} \\
1.34 \mathrm{~m}\end{array}$ & $24.2, \mathrm{CH}_{2}$ \\
\hline $5^{\prime}$ & $4.09 \mathrm{q}(6.5)$ & $65.3, \mathrm{CH}$ & $4.06 \mathrm{q}(6.8)$ & $65.4, \mathrm{CH}$ & $1.08 \mathrm{~m}$ & 37.2, $\mathrm{CH}_{2}$ \\
\hline $6^{\prime}$ & $1.28 \mathrm{~d}(6.5)$ & $16.1, \mathrm{CH}_{3}$ & $1.27 \mathrm{~d}(6.8)$ & $16.1, \mathrm{CH}_{3}$ & $1.38 \mathrm{~m}$ & $32.7, \mathrm{CH}$ \\
\hline $7^{\prime}$ & & & & & $\begin{array}{l}1.08 \mathrm{~m} \\
1.26 \mathrm{~m}\end{array}$ & $37.3, \mathrm{CH}_{2}$ \\
\hline $8^{\prime}$ & & & & & $1.24 \mathrm{~m}$ & 21.3, $\mathrm{CH}_{2}$ \\
\hline $9^{\prime}$ & & & & & $1.70 \mathrm{~m}$ & $41.0, \mathrm{CH}_{2}$ \\
\hline $10^{\prime}$ & & & & & & $82.5, \mathrm{C}$ \\
\hline $11^{\prime}$ & & & & & $1.42 \mathrm{~s}$ & 26.1, $\mathrm{CH}_{3}$ \\
\hline $12^{\prime}$ & & & & & $1.42 \mathrm{~s}$ & $26.1, \mathrm{CH}_{3}$ \\
\hline $13^{\prime}$ & & & & & $0.85 \mathrm{~d}(6.4)$ & 19.6, $\mathrm{CH}_{3}$ \\
\hline $14^{\prime}$ & & & & & $0.93 \mathrm{~d}(6.0)$ & $19.9, \mathrm{CH}_{3}$ \\
\hline OAc & $2.06 \mathrm{~s}$ & 21.1, $\mathrm{CH}_{3}$ & $2.12 \mathrm{~s}$ & 21.1, $\mathrm{CH}_{3}$ & $1.97 \mathrm{~s}$ & $22.5, \mathrm{CH}_{3}$ \\
\hline & $2.13 \mathrm{~s}$ & $\begin{array}{c}21.2, \mathrm{CH}_{3} \\
171.3, \mathrm{C} \\
171.5, \mathrm{C}\end{array}$ & & $171.5, \mathrm{C}$ & & $170.5, \mathrm{C}$ \\
\hline
\end{tabular}

${ }^{\mathrm{a}}$ Spectra recorded at $500 \mathrm{MHz}$ in $\mathrm{CDCl}_{3} ;{ }^{\mathrm{b}}$ Spectra recorded at $125 \mathrm{MHz}$ in $\mathrm{CDCl}_{3} ;{ }^{\mathrm{c}}$ Spectra recorded at $400 \mathrm{MHz}$ in $\mathrm{CDCl}_{3} ;{ }^{\mathrm{d}}$ Spectra recorded at $100 \mathrm{MHz}$ in $\mathrm{CDCl}_{3} ;{ }^{\mathrm{e}}$ Deduced from DEPT; ${ }^{\mathrm{f}} J$ values (Hz) in parentheses.

3-Methyl-5-(10'-acetoxy-2',6',10'-trimethylundecyl)-2-penten-5-olide (6) was obtained as colorless oil with $[\alpha]_{\mathrm{D}}^{25}-22\left(c 0.17, \mathrm{CHCl}_{3}\right)$. The HRESIMS of 6 exhibited a $[\mathrm{M}+\mathrm{Na}]^{+}$peak at $\mathrm{m} / \mathrm{z} 389.2666$, and established a molecular formula of $\mathrm{C}_{22} \mathrm{H}_{38} \mathrm{O}_{4}$, implying four degrees of unsaturation. Above information and the UV absorption at $211 \mathrm{~nm}$ and the IR absorption at $1729 \mathrm{~cm}^{-1}$ suggested the presence of an $\alpha, \beta$-unsaturated $\delta$-lactone [19]. The ${ }^{13} \mathrm{C}$ NMR and DEPT spectroscopic data (Table 2) showed 22 carbon signals, including six methyls, eight $\mathrm{sp}^{3}$ methylenes, three $\mathrm{sp}^{3}$ methines, one $\mathrm{sp}^{2}$ methine, three $\mathrm{sp}^{2}$ quaternary and one $\mathrm{sp}^{3}$ quaternary carbons. The signals in the ${ }^{1} \mathrm{H}$ NMR spectrum at $\delta_{\mathrm{H}}(5.81,1 \mathrm{H}, \mathrm{s}), 2.22(1 \mathrm{H}, \mathrm{d}, J=4.4 \mathrm{~Hz}), 2.27(1 \mathrm{H}, \mathrm{m}), 4.46(1 \mathrm{H}, \mathrm{m})$, and $1.99(3 \mathrm{H}, \mathrm{s})$ verified the presence of a subunit of 3-methyl-2-penten-5-olide [20,21]. The planar structure and all of the ${ }^{1} \mathrm{H}$ and ${ }^{13} \mathrm{C}$ chemical shifts of 6 were elucidated by 2D NMR experiments, in particular the ${ }^{1} \mathrm{H}-{ }^{1} \mathrm{H}$ COSY and HMBC experiments (Figure 1). The HMBC correlations from $\mathrm{H}_{2}-5$ to $\mathrm{C}-4$ and $\mathrm{C}-1^{\prime} ; \mathrm{H}_{3}-11^{\prime}$ to $\mathrm{C}-9^{\prime}$ and C-10'; $\mathrm{H}_{3}-12^{\prime}$ to $\mathrm{C}-10^{\prime} ; \mathrm{H}_{3}-13^{\prime}$ to $\mathrm{C}-5^{\prime}$ and $\mathrm{C}-6^{\prime} ; \mathrm{H}_{3}-14^{\prime}$ to $\mathrm{C}-1^{\prime}, \mathrm{C}-2^{\prime}$ and $\mathrm{C}-3^{\prime}$; and $\mathrm{H}_{3}-6$ to $\mathrm{C}-3$ and C-4. The structure of $\mathbf{6}$ thus was established and was found to be a $\alpha, \beta$-unsaturated $\delta$-lactone, 3-methyl-5-(10'-acetoxy-2',6',10'-trimethylundecyl)-2-penten-5-olide, which is a new chemotype of diterpene.

The cytotoxicity of compounds 3-5 against the proliferation of a limited panel of cancer cell lines, including HepG2, A549, and MDA-MB-231 carcinoma cell lines was evaluated. The results showed 
that compound 4 exhibited moderate cytotoxicity against HepG2, A549, and MDA-MB-231 with IC $_{50}$ values of $23.3,21.9$, and $24.3 \mu \mathrm{M}$, respectively. The anti-inflammatory activities of $\mathbf{1}, \mathbf{2}$, and 4-6 against the accumulation of pro-inflammatory iNOS and COX-2 proteins in RAW264.7 macrophage cells stimulated with LPS, were also evaluated using immunoblot analysis (Figure 3). At a concentration of $10 \mu \mathrm{M}$, compounds 2 , and 4 significantly reduced the levels of iNOS protein to $28.4 \pm 8.4 \%$, and $27.2 \pm 9.0 \%$, respectively, relative to control cells stimulated with LPS only. Meanwhile, compounds $\mathbf{1}, \mathbf{5}$, and $\mathbf{6}$ moderately reduced iNOS level to $72.8 \pm 9.5 \%, 60.3 \pm 9.7 \%$, and $61.8 \pm 9.8 \%$, respectively. At the same concentration, compounds 1, 2, and 4-6 also could reduce COX-2 expression to $28.4 \pm 4.9 \%$, $9.0 \pm 4.4 \%, 11.8 \pm 6.8 \%, 26.6 \pm 10.0 \%$, and $61.7 \pm 8.3 \%$, respectively. These results indicated that compounds 2 and 4 might become the effective anti-inflammatory agents as they can potently inhibit the expression of both iNOS and COX-2 proteins in LPS-induced macrophage cells. Compounds 1 and 5 might also be useful anti-inflammatory compounds as they could effectively reduce COX-2 expression, too. Thus, soft coral $S$. gracillimum is an important source of anti-inflammatory agents, as except 1, 2, 4 and 5, effective anti-inflammatory compounds sclerosteroids A (7), B (8), and E (9) (Chart 2) were also discovered from this organism by our previous investigation [7]. The exhibited anti-inflammatory activity for sclerosteroids $\mathrm{A}, \mathrm{B}, \mathrm{E}, \mathrm{J}, \mathrm{K}, \mathrm{M}$, and $\mathrm{N}$ revealed that the oxidation at $\mathrm{C}-19$ in pregnanes could enhance anti-inflammatory activity.

Figure 3. Effect of isolates $(10 \mu \mathrm{M})$ from $S$. gracillimum on the lipopolysaccharide (LPS)-induced pro-inflammatory iNOS and on COX-2 protein expression of RAW264.7 macrophage cells by immunoblot analysis. (A) Immunoblots iNOS and $\beta$-actin; (B) Immunoblots COX-2 and $\beta$-actin. The values are means $\pm \operatorname{SEM}(n=6)$. The relative intensity of the LPS alone stimulated group was taken as $100 \%$. * Significantly different from LPS alone stimulated group $(* p<0.05) .{ }^{\text {a }}$ stimulated with LPS; ${ }^{\mathrm{b}}$ stimulated with LPS in the presence of $\mathbf{1}, \mathbf{2}$, and $4-6(10 \mu \mathrm{M})$.
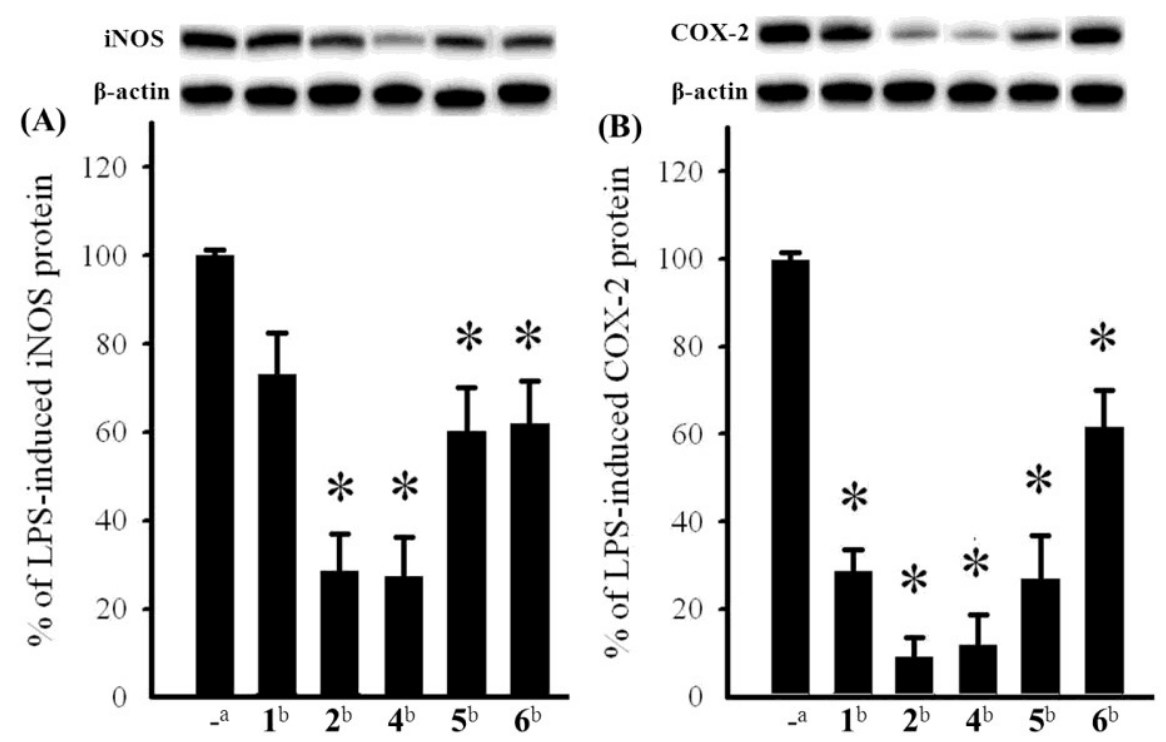
Chart 2. Structures of known anti-inflammatory compounds 7-9.
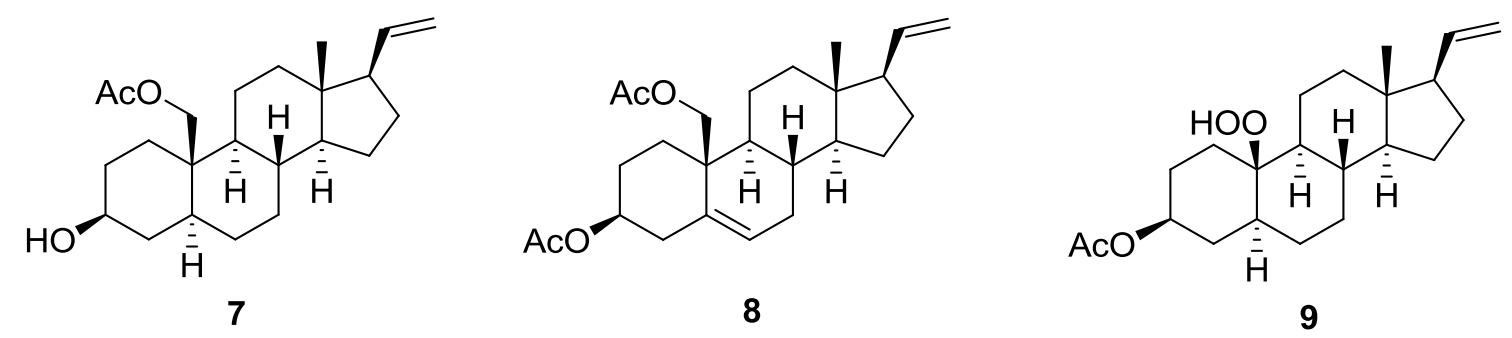

\section{Experimental Section}

\subsection{General Experimental Procedures}

Melting point was determined using a Fisher-Johns melting point apparatus. Optical rotations were measured with a JASCO P-1020 polarimeter. Ultraviolet spectrum was recorded on a JASCO V-650 spectrophotometer. IR spectrum was recorded on a JASCO FT/IR-4100 spectrophotometer. The NMR spectra were recorded on a Varian MR-400 FT-NMR or Varian Unity INOVA 500 FT-NMR instrument at $400 \mathrm{MHz}$ or $500 \mathrm{MHz}$ for ${ }^{1} \mathrm{H}$ (referenced to TMS, $\delta_{\mathrm{H}} 7.27 \mathrm{ppm}$ for $\mathrm{CDCl}_{3}$ ) and 100 or $125 \mathrm{MHz}$ for ${ }^{13} \mathrm{C}$ (referenced to $\delta_{\mathrm{C}} 77.0$ for $\mathrm{CDCl}_{3}$ ). ESIMS and HRESIMS were recorded by ESI FT-MS on a Bruker APEX II mass spectrometer. Silica gel 60 (Merck, 230-400 mesh) was used for column chromatography. Precoated silica gel plates (Merck, Kieselgel $60 \mathrm{~F}_{254}, 0.25 \mathrm{~mm}$ ) and precoated RP-18 $\mathrm{F}_{254 \mathrm{~S}}$ plates (Merck, 1.05560) were used for TLC analyses. High-performance liquid chromatography (HPLC) was performed on a Hitachi L-7100 pump equipped with a Hitachi L-7400 UV detector and a semi-preparative reversed-phase column (YMC-Pack Pro C18, $5 \mu \mathrm{m}, 250 \times 10 \mathrm{~mm}$ ).

\subsection{Animal Material}

The soft coral Scleronephthya gracillimum was collected at Green Island, Taiwan, in January, 2008, at a depth of $10 \mathrm{~m}$, and was stored in a freezer until extraction. This soft coral was identified by one of the authors (C.-F.D.). A voucher specimen (NSYSU-SG001) was deposited in the Department of Marine Biotechnology and Resources, National Sun Yat-sen University.

\subsection{Extraction and Isolation}

The frozen bodies of $S$. gracillimum $(1.3 \mathrm{~kg}$, fresh wet) were minced and extracted with EtOH $(3 \mathrm{~L} \times 2)$. The organic extract was concentrated to an aqueous suspension which was further partitioned between EtOAc and $\mathrm{H}_{2} \mathrm{O}$. The EtOAc extract ( $9.6 \mathrm{~g}$ ) was fractionated by open column chromatography on silica gel using $n$-hexane-EtOAc and EtOAc-MeOH mixtures of increasing polarity to yield 40 fractions. Fraction 13, eluting with $n$-hexane-EtOAc (4:1), was further separated by silica gel column chromatography ( $n$-hexane-EtOAc, 10:1) and followed by reversed-phase HPLC $\left(\mathrm{MeOH}-\mathrm{H}_{2} \mathrm{O}, 85: 15\right)$ to afford $1(1.0 \mathrm{mg}), 2(1.0 \mathrm{mg})$, and $\mathbf{6}(1.7 \mathrm{mg})$. Fraction 14, eluting with $n$-hexane-EtOAc (2:1), was further separated by silica gel column chromatography ( $n$-hexane-EtOAc, 10:1) and followed by reversed-phase HPLC $\left(\mathrm{MeOH}-\mathrm{H}_{2} \mathrm{O}, 85: 15\right)$ to afford $3(0.9 \mathrm{mg})$. Fraction 18, eluting with $n$-hexane-EtOAc (1:6), was rechromatographed over a Sephadex LH-20 column using acetone as the 
mobile phase to afford six subfractions (A1-A6). Subfractions A2 was separated by reversed-phase HPLC $\left(\mathrm{CH}_{3} \mathrm{CN}-\mathrm{H}_{2} \mathrm{O}, 75: 25\right)$ to afford compounds 4 (2.0 mg), and 5 (2.5 mg).

Sclerosteroid J (1): colorless oil; $[\alpha]_{\mathrm{D}}^{25}-60\left(c 0.1, \mathrm{CHCl}_{3}\right)$; IR (neat) $v_{\max } 2926,2865,1739,1576$, 1452, 1236, and $1051 \mathrm{~cm}^{-1} ;{ }^{13} \mathrm{C}$ and ${ }^{1} \mathrm{H}$ NMR data, see Table 1 ; ESIMS $\mathrm{m} / z 427[\mathrm{M}+\mathrm{Na}]^{+}$; HRESIMS $m / z 427.2827[\mathrm{M}+\mathrm{Na}]^{+}$(calcd for $\mathrm{C}_{25} \mathrm{H}_{40} \mathrm{O}_{4} \mathrm{Na}, 427.2824$ ).

Sclerosteroid K (2): colorless oil; $[\alpha]_{\mathrm{D}}^{25}-41$ (c 0.1, $\mathrm{CHCl}_{3}$ ); IR (neat) $v_{\max } 2926,2870,1744,1677$, 1233, and $1036 \mathrm{~cm}^{-1}$; UV (MeOH) $\lambda_{\max } 239(\log \varepsilon=4.2) ;{ }^{13} \mathrm{C}$ and ${ }^{1} \mathrm{H}$ NMR data, see Table 1; ESIMS $m / z 379[\mathrm{M}+\mathrm{Na}]^{+}$; HRESIMS m/z 379.2251 [M+ Na] ${ }^{+}$(calcd for $\mathrm{C}_{23} \mathrm{H}_{32} \mathrm{O}_{3} \mathrm{Na}, 379.2249$ ).

Sclerosteroid L (3): white powder; mp $150-152{ }^{\circ} \mathrm{C}$; $[\alpha]_{\mathrm{D}}^{25}-18\left(c 0.07, \mathrm{CHCl}_{3}\right)$; IR (neat) $v_{\max } 3568$, 2922, 2870, 1712, 1244, and $1025 \mathrm{~cm}^{-1} ;{ }^{13} \mathrm{C}$ and ${ }^{1} \mathrm{H}$ NMR data, see Table 1; ESIMS $\mathrm{m} / z 383[\mathrm{M}+\mathrm{Na}]^{+}$; HRESIMS $m / z$ 383.2559 [M+Na] $]^{+}$(calcd for $\mathrm{C}_{23} \mathrm{H}_{36} \mathrm{O}_{3} \mathrm{Na}, 383.2562$ ).

Sclerosteroid M (4): yellow oil; $[\alpha]_{\mathrm{D}}^{25}-60\left(c 0.1, \mathrm{CHCl}_{3}\right)$; IR (neat) $v_{\max } 3448,2926,2868,1739$, 1369, 1241, and $1034 \mathrm{~cm}^{-1} ;{ }^{13} \mathrm{C}$ and ${ }^{1} \mathrm{H}$ NMR data, see Table 2; ESIMS $m / z 571[\mathrm{M}+\mathrm{Na}]^{+}$; HRESIMS $m / z 571.3249[\mathrm{M}+\mathrm{Na}]^{+}$(calcd for $\mathrm{C}_{31} \mathrm{H}_{48} \mathrm{O}_{8} \mathrm{Na}, 571.3247$ ).

Sclerosteroid N (5): colorless oil; $[\alpha]_{\mathrm{D}}^{25}-24$ (c 0.25, $\left.\mathrm{CHCl}_{3}\right)$; IR (neat) $v_{\max } 3390,2926,2870,1739$, 1374, 1250, and $1036 \mathrm{~cm}^{-1} ;{ }^{13} \mathrm{C}$ and ${ }^{1} \mathrm{H}$ NMR data, see Table 2; ESIMS $\mathrm{m} / z 527[\mathrm{M}+\mathrm{Na}]^{+}$; HRESIMS $m / z 527.2989[\mathrm{M}+\mathrm{Na}]^{+}$(calcd for $\mathrm{C}_{29} \mathrm{H}_{44} \mathrm{O}_{7} \mathrm{Na}, 527.2985$ ).

3-Methyl-5-(10'-acetoxy-2',6',10'-trimethylundecyl)-2-penten-5-olide (6): colorless oil; $[\alpha]_{\mathrm{D}}^{25}-22$ (c $0.17, \mathrm{CHCl}_{3}$ ); IR (neat) $v_{\max } 2926,2865,1729,1363,1250$, and $1014 \mathrm{~cm}^{-1}$; UV (MeOH) $\lambda_{\max } 211$ $(\log \varepsilon=4.0) ;{ }^{13} \mathrm{C}$ and ${ }^{1} \mathrm{H}$ NMR data, see Table 2; ESIMS $m / z 389[\mathrm{M}+\mathrm{Na}]^{+}$; HRESIMS $m / z 389.2666$ $[\mathrm{M}+\mathrm{Na}]^{+}$(calcd for $\mathrm{C}_{22} \mathrm{H}_{38} \mathrm{O}_{4} \mathrm{Na}, 389.2668$ ).

\subsection{Cytotoxicity Testing}

Cell lines were purchased from the American Type Culture Collection (ATCC). Cytotoxicity assays of compounds 1-6 were performed using the MTT [3-(4,5-dimethylthiazol-2-yl)-2,5-diphenyl-tetra zolium bromide] colorimetric method [22,23].

\subsection{In Vitro Anti-Inflammatory Assay}

Macrophage (RAW264.7) cell line was purchased from ATCC. In vitro anti-inflammatory activities of tested compounds were measured by examining the inhibition of lipopolysaccharide (LPS) induced upregulation of iNOS (inducible nitric oxide synthase) and COX-2 (cyclooxygenase-2) proteins in macrophages cells using western blotting analysis [24,25].

\section{Conclusions}

Our present investigation again demonstrated that the Formosan soft coral Scleronephthya gracillimum could be a source of anti-inflammatory natural products. Anti-inflammatory activity assay revealed that compounds 1,2 and 4-6, in particular 2 and 4, and the previously discovered 
pregnanes sclerosteroids A, B, and E, deserve further study for therapeutic potential against inflammation-related diseases.

\section{Acknowledgements}

This work was supported by a grant from National Science Council of Taiwan NSC-100-2320-B-110-001-MY2 to J.-H.S.

\section{References}

1. Blunt, J.W.; Copp, B.R.; Keyzers, R.A.; Munro, M.H.G.; Prinsep, M.R. Marine natural products. Nat. Prod. Rep. 2012, 29, 144-222.

2. Huo, J.; Tang, H.; Li, L.; Liu, B.-S.; Sun, P.; Yi, Y.-H.; Zhang, W. Study on bioactive constituents of the South China Sea soft coral Scleronephthya sp. Acad. J. Sec. Mil. Med. Univ. 2011, 32, $21-24$.

3. Han, L.; Wang, C.-Y.; Huang, H.; Shao, C.-L.; Liu, Q.-A.; Qi, J.; Sun, X.-P.; Zhai, P.; Gu, Y.-C. A new pregnane analogue from Hainan soft coral Scleronephthya gracillimum Kükenthal. Biochem. Syst. Ecol. 2010, 38, 243-246.

4. Yan, X.-H.; Liu, H.-L.; Guo, Y.-W. Ximaosteroids A-D, new steroids from the Hainan soft coral Scleronephthya sp. Steroids 2009, 74, 1061-1065.

5. Yan, X.-H.; Guo, Y.-W.; Zhu, X.-Z.; Mollo, E.; Cimino, G. Studies on Chemical Constituents of the Soft Coral Scleronephthya sp. from the South China Sea. Chin. J. Org. Chem. 2004, 24, 1233-1238.

6. Kittakoop, P.; Suttisri, R.; Chaichantipyuth, C.; Vethchagarun, S.; Suwanborirux, K. Norpregnane glycosides from a Thai soft coral, Scleronephthya pallida. J. Nat. Prod. 1999, 62, 318-320.

7. Fang, H.-Y.; Liaw, C.-C.; Chao, C.-H.; Wen, Z.-H.; Wu, Y.-C.; Hsu, C.-H.; Dai, C.-F.; Sheu, J.-H. Bioactive pregnane-type steroids from the soft coral Scleronephthya gracillimum. Tetrahedron 2012, 68, 9694-9700.

8. Zhao, H.Y.; Shao, C.L.; Li, Z.Y.; Han, L.; Cao, F.; Wang, C.Y. Bioactive pregnane steroids from a South China sea gorgonian Carijoa sp. Molecules 2013, 18, 3458-3466.

9. Chao, C.-H.; Wen, Z.-H.; Su, J.-H.; Chen, I.-M.; Huang, H.-C.; Dai, C.-F.; Sheu, J.-H. Further study on anti-inflammatory oxygenated steroids from the octocoral Dendronephthya griffini. Steroids 2008, 73, 1353-1358.

10. Tomono, Y.; Hirota, H.; Imahara, Y.; Fusetani, N. Four new steroids from two octocorals. J. Nat. Prod. 1999, 62, 1538-1541.

11. Ioannou, E.; Abdel-Razik, A.F.; Alexi, X.; Vagias, C.; Alexis, M.N.; Roussis, V. Pregnanes with antiproliferative activity from the gorgonian Eunicella cavolini. Tetrahedron 2008, 64, 11797-11801.

12. Kashman, Y.; Green, D.; Garcia, C.; Garcia Arevalos, D. Verrucoside, a new cytotoxic pregnane glycoside from a gorgonian Eunicella verrucosa. J. Nat. Prod. 1991, 54, 1651-1655.

13. Gutiérrez, M.; Capson, T.L.; Guzmán, H.M.; González, J.; Ortega-Barría, E.; Quiñoá, E.; Riguera, R. Antiplasmodial metabolites isolated from the marine octocoral Muricea austera. J. Nat. Prod. 2006, 69, 1379-1383. 
14. Wang, S.-K.; Dai, C.-F.; Duh, C.-Y. Cytotoxic pregnane steroids from the Formosan soft coral Stereonephthya crystallina. J. Nat. Prod. 2006, 69, 103-106.

15. Qi, S.H.; Zhang, S.; Yang, L.H.; Qian, P.Y. Antifouling and antibacterial compounds from the gorgonians Subergorgia suberosa and Scripearia gracillis. Nat. Prod. Res. 2008, 22, 154-166.

16. Krubiner, A.M.; Gottfried, N.; Oliveto, E.P. The synthesis of 17-deoxy-17- $\alpha$ and $-17 \beta 20$-pregnynes and -20-pregnenes. J. Org. Chem. 1969, 34, 3502-3505.

17. Wu, S.-L.; Wang, G.-H.; Dai, C.-F.; Sheu, J.-H. Pregnane-based steroids from a Formosan gorgonian Subergorgia mollis. J. Chin. Chem. Soc. 2004, 51, 205-208.

18. Higgs, M.D.; Faulkner, D.J. 5 $\alpha$-Pregna-1,20-dien-3-one and related compounds from a soft coral. Steroids 1977, 30, 379-388.

19. Gueldner, R.C.; Thompson, A.C.; Hedin, P.A. Stereoselective synthesis of racemic grandisol. J. Org. Chem. 1972, 37, 1854-1856.

20. Shimomura, H.; Sashida, Y.; Mimaki, Y.; Adachi, T.; Yoshinari, K. A new mevalonolactone glucoside derivative from the bark of Prunus buergeriana. Chem. Pharm. Bull. 1989, 37, 829-830.

21. Henrick, C.A.; Willy, W.E.; Mckean, D.R.; Baggiolini, E.; Siddall, J.B. Approaches to the synthesis of the insect juvenile hormone analog ethyl 3,7,11-trimethyl-2,4-dodecadienoate and its photochemistry. J. Org. Chem. 1975, 40, 8-14.

22. Alley, M.C.; Scudiero, D.A.; Monks, A.; Hursey, M.L.; Czerwinski, M.J.; Fine, D.L.; Abbott, B.J.; Mayo, J.G.; Shoemaker, R.H.; Boyd, M.R. Feasibility of drug screening with panels of human tumor cell lines using a microculture tetrazolium assay. Cancer Res. 1988, 48, 589-601.

23. Scudiero, D.A.; Shoemaker, R.H.; Paull, K.D.; Monks, A.; Tierney, S.; Nofziger, T.H.; Currens, M.J.; Seniff, D.; Boyd, M.R. Evaluation of a soluble tetrazolium/formazan assay for cell growth and drug sensitivity in culture using human and other tumor cell lines. Cancer Res. 1988, $48,4827-4833$.

24. Lu, Y.; Huang, C.-Y.; Lin, Y.-F.; Wen, Z.-H.; Su, J.-H.; Kao, Y.-H.; Chiang, M.-Y.; Sheu, J.-H. Anti-inflammatory cembranoids from the soft corals Sinularia querciformis and Sinularia granosa. J. Nat. Prod. 2008, 71, 1754-1759.

25. Jean, Y.-H.; Chen, W.-F.; Sung, C.-S.; Duh, C.-Y.; Huang, S.-Y.; Lin, C.-S.; Tai, M.-H.; Tzeng, S.-F.; Wen, Z.-H. Capnellene, a natural marine compound derived from soft coral, attenuates chronic constriction injury-induced neuropathic pain in rats. Br. J. Pharmacol. 2009, $158,713-725$.

Samples Availability: Not available.

(C) 2013 by the authors; licensee MDPI, Basel, Switzerland. This article is an open access article distributed under the terms and conditions of the Creative Commons Attribution license (http://creativecommons.org/licenses/by/3.0/). 